\author{
Anuário do Instituto de Geociências - UFRJ \\ www.anuario.igeo.ufrj.br
}

\title{
Continuous Diffusion Pb Loss in Igneous Zircon: A BSE, ID-TIMS and Raman Spectroscopy Study on a Mesoproterozoic Granite from the SW Amazonian Craton Perda de $\mathrm{Pb}$ por Difusão Contínua em Zircão Ígneo: Estudo da Espectroscopia BSE, ID-TIMS e Raman em Granito Mesoproterozoico do SW do Cráton Amazônico
}

\author{
Armando Dias Tavares Júnior'1; Mauro Cesar Geraldes²; \\ Anderson Costa dos Santos ${ }^{2} \&$ Werlem Holanda dos Santos ${ }^{2}$
}

\author{
${ }^{1}$ Universidade do Estado do Rio de Janeiro, Instituto de Física, Departamento de Eletrônica Quântica, \\ Rua São Francisco Xavier, 524, sala 4029, Bloco A, 20550-013, Maracanã, Rio de Janeiro, RJ, Brasil \\ ${ }^{2}$ Universidade do Estado do Rio de Janeiro, Instituto de Física, Departamento de Eletrônica Quântica, \\ Rua São Francisco Xavier, 524, sala 4029, Bloco A, 20550-013, Maracanã, Rio de Janeiro, RJ, Brasil \\ E-mails: tavares@uerj.br; geraldes@uerj.br; andcostasantos@uerj.br;werlem.santos@uerj.br \\ Recebido em: 12/09/2018 Aprovado em: 25/02/2019 \\ DOI: http://dx.doi.org/10.11137/2019_1_483_489
}

\begin{abstract}
This work presents a detailed investigation on zircon crystals of a Mesoproterozoic granite from the SW Amazonian Craton using a combination of back scattered electron (BSE) imaging, thermal ionisation mass spectrometry (TIMS) and Raman scattering spectroscopy. Six zircon grains were analysed. The results plotted in the Concordia diagram yielded an upper intercept age of 1423.0 $\pm 3.8 \mathrm{Ma}$, which is interpreted as the crystallization age of the rock. The scattering of the analyses in such diagram indicates that $\mathrm{U}-\mathrm{Pb}$ isotopes are volume-dependent in the studied zircon grains. BSE reveals zonation in the zircon crystals, and Hf is the main element causing the variability in the BSE intensity and $U$ has a secondary effect. Both elements have much higher atomic number than the principal constituents of zircon ( $\mathrm{Zr}, \mathrm{Si}$ and $\mathrm{O}$ ), so the substitution of $\mathrm{Zr}$ by U and Hf results in increasing image brightness. BSE images from the zircon grains exhibit a euhedral external shape and fine-scale euhedral oscillatory zoning. The predominance of magmatic zoned crystals points out that the granite has not suffered metamorphic heating or any other processes that induce the formation of new phases. The results of the Raman scattering technique indicate that a $\mathrm{SiO}_{4}$ tetrahedral internal vibrational structure is sufficiently sensitive to determine the increasing degree of metamictization. Furthermore, evidence for metamictization is given by the heterogeneity of the half-width values of the Raman scattering peaks, which exhibit a decreasing trend from the core to the rims of the analysed grains. We concluded that the combination of the three techniques provides information on the $\mathrm{Pb}$ loss and that the degree of $\mathrm{U}-\mathrm{Pb}$ isotopic discordance correlates closely with the volume of the zircon grain. The data, in addition to the lateral degree of metamictization detected by the Raman scattering technique, indicate that the loss of radiogenic $\mathrm{Pb}$ may be linked to the continuous diffusion of this element. The correlation of the U-Pb discordance and metamictization emphasizes the importance of the Raman scattering spectroscopy analysis to performing zircon dating. Indeed, it is a helpful tool for geochronologists.
\end{abstract}

Keywords: zircon; TIMS; SW Amazonian Craton

\section{Resumo}

Uma investigação detalhada de grãos de zircão a partir de um granito Mesoproterozoico do SW do Cráton Amazônico usando uma combinação de imagens de elétrons retro espalhados (BSE), espectrometria de massa por ionização térmica (TIMS) e espectroscopia de espalhamento Raman é apresentada neste trabalho. Foram analisados seis cristais de zircão e os resultados traçados no diagrama de Concordia forneceram uma idade de intercepto superior de $1423 \pm 3,8 \mathrm{Ma}$, que é interpretada como a idade de cristalização da rocha. Os resultados, quando plotados em tal diagrama, indicam que os isótopos de U-Pb dependem do volume nos grãos de zircão estudados. A BSE revela zoneamento nos cristais, com Hf como principal elemento responsável pela variabilidade na intensidade da BSE e com U tendo um efeito secundário. Ambos os elementos têm um número atômico muito maior do que os constituintes principais do zircão ( $\mathrm{Zr}$, Si e O), de modo que a substituição de $\mathrm{Zr}$ por U e Hf resulta em maior brilho da imagem. As imagens de BSE dos grãos de zircão exibem zoneamento indicando que o granito não sofreu aquecimento metamórfico ou qualquer outro processo que induzisse à formação de novas fases. Os resultados da técnica de espalhamento Raman indicam que uma estrutura vibracional interna tetraédrica $\left(\mathrm{SiO}_{4}\right)$ é suficientemente sensível para determinar o grau crescente de metamictização. Além disso, a evidência de metamictização é dada pela heterogeneidade dos valores de meia largura dos picos de dispersão Raman, que apresentam uma tendência decrescente do centro para as bordas dos grãos analisados. Concluímos que a combinação das três técnicas fornece informações sobre a perda de $\mathrm{Pb}$ e que o grau de discordância isotópica de $\mathrm{U}-\mathrm{Pb}$ correlaciona-se estreitamente com o volume do grão de zircão. Os dados, além do grau lateral de metamictização detectado pela técnica de espalhamento Raman, indicam que a perda de $\mathrm{Pb}$ radiogênico pode estar ligada à difusão contínua desse elemento. A correlação da discordância U-Pb com a metamictização ressalta a importância da obtenção de análise por espectroscopia de dispersão Raman em zircão para a datação, sendo uma ferramenta útil para os geocronologistas.

Palavras-chave: Zircão; TIMS; SW Cráton Amazônico 


\section{Introduction}

The metamictization of zircon has been the subject of extensive research (Nasdala et al. 1996, 1998a, 1998b, 1999; Wopenka et al. 1996; Hartmann et al. 1997; Poller et al. 1997; Balan et al. 2001). Understanding how the zircon structure responds to radiation damage is important for both the storage of high-level radioactive waste (Ewing et al. 1995) and the use of U-Th-Pb isotopic systematics. In the latter case, fracturing due to the volume expansion that accompanies metamictization may lead to diffuse loss or heterogeneous redistribution of radiogenic $\mathrm{Pb}$ (Pidgeon, 1992).

The metamictization of zircon can be characterised by Raman scattering spectroscopy (Knittle \& Willians, 1993; Jolliff et al. 1995). The Raman scattering method has advantages: little or no sample preparation is necessary, and the analysis can be performed in a reasonable amount of time. Particularly important is the ability of Raman spectroscopy to determine the crystallinity of micro-areas, allowing for the determination of such information by profiling across zircon grains (Jolliff et al. 1995). In addition, BSE images provide complete information about the internal structures of zircon grains (Poller et al. 1997). As earlier investigations have demonstrated (Harchar \& Miller, 1993), the parallel use of the BSE pre-investigating method allows for the inherited cores, desorbed areas and magmatic zonation to be distinguished. Thus, BSE is an important tool to solve the main problem involved in achieving successful zircon dating: the selection of the appropriate grains.

We present a detailed investigation on zircon grains from a Mesoproterozoic granite of the SW
Amazonian Craton using a combination of back scattered electron (BSE) imaging, thermal ionisation mass spectrometry (TIMS) and Raman scattering spectroscopy. The objective of this work is to study the correlation between metamictization and the $\mathrm{U}-\mathrm{Pb}$ isotopic discordance of zircon.

\section{Procedures}

For the U-Pb analyses, the separation of zircon grains was performed using the standard procedures. U-Pb zircon analyses were performed at the Isotope Geochemistry Laboratory (IGL), Department of Geology, University of Kansas (USA). The details of the procedures are found in Geraldes et al. (2001). A smaller magnetic fraction was abraded, and handpicked single grains were spiked with ${ }^{205} \mathrm{~Pb}$ ${ }^{235} \mathrm{U}$ mixed tracer. The zircon grains were dissolved, and then, $\mathrm{Pb}$ and $\mathrm{U}$ were separated using procedures modified after Krogh $(1973,1982)$ and Parrish (1987). The zircon weights varied from 0.002 to $0.018 \mathrm{mg}$. The isotopic ratios were measured using a VG Sector Multi-collector mass spectrometer in the single collector mode using a Daly detector. Table 1 exhibits the obtained analyses of the selected zircon crystals.

$\mathrm{Pb}$ isotope compositions were analysed on single Re filaments using silica gel and phosphoric acid. Uranium was loaded with $\mathrm{Pb}$ in the same filament and analysed as $\mathrm{UO}_{2}^{+}$. The amounts of radiogenic ${ }^{208} \mathrm{~Pb}$, ${ }^{207} \mathrm{~Pb}$, and ${ }^{206} \mathrm{~Pb}$ were calculated using $\mathrm{Pb}$ laboratory blank correction (from 7 to $17 \mathrm{pg}$ total $\mathrm{Pb}$ during the analyses) and for non-radiogenic common $\mathrm{Pb}$ corresponding to the model of Stacey \& Krammers (1975) for the approximate age of the sample.

\begin{tabular}{|c|c|c|c|c|c|c|c|}
\hline Grain & Weight $(\mathrm{mg})$ & ${ }^{206} \mathrm{~Pb} /{ }^{238} \mathrm{U}$ & ${ }^{207} \mathrm{~Pb} /{ }^{235} \mathrm{U}$ & ${ }^{207} \mathrm{~Pb} /{ }^{206} \mathrm{~Pb}$ & ${ }^{206} \mathrm{~Pb}{ }^{232} \mathrm{U}(\mathrm{Ma})$ & ${ }^{207} \mathrm{~Pb} /{ }^{235} \mathrm{U}(\mathrm{Ma})$ & ${ }^{207} \mathrm{~Pb} /{ }^{206} \mathrm{~Pb}(\mathrm{Ma})$ \\
\hline $\mathrm{M}(-1) \mathrm{D}[1]$ & 0.016 & 0.246143 & 1420 & 0.0898859 & 1419 & 1420 & 1423 \\
\hline $\mathrm{M}(-1) \mathrm{M}[1]$ & 0.015 & 0.243205 & 1411 & 0.0898999 & 1403 & 1411 & 1423 \\
\hline $\mathrm{NM}(-1) \mathrm{L}[1]$ & 0.01 & 0.241126 & 1406 & 0.0900346 & 1393 & 1406 & 1426 \\
\hline $\mathrm{M}(-1) \mathrm{A}[1]$ & 0.006 & 0.235062 & 1386 & 0.0899631 & 1361 & 1386 & 1425 \\
\hline $\mathrm{M}(-1) \mathrm{C}[1]$ & 0.003 & 0.235215 & 1388 & 0.0900809 & 1362 & 1388 & 1427 \\
\hline $\mathrm{M}(-1) \mathrm{B}[1]$ & 0.002 & 0.238882 & 1397 & 0.0898542 & 1380 & 1397 & 1422 \\
\hline
\end{tabular}

Table $1 \mathrm{U}-\mathrm{Pb}$ results of 6 single zircon grains from a granitic rock. 
The decay constants used were $0.155125 \times$ $10^{-9}$ year $^{-1}$ for ${ }^{238} \mathrm{U}$ and $0.98485 \times 10^{-9}$ year $^{-1}$ for ${ }^{235} \mathrm{U}$ (Steiger \& Jäger, 1977). The zircon data were regressed using the ISOPLOT program of Ludwig (1998). Uncertainties in the Concordia intercept ages are given at the 2 sigma $(\sigma)$ level.

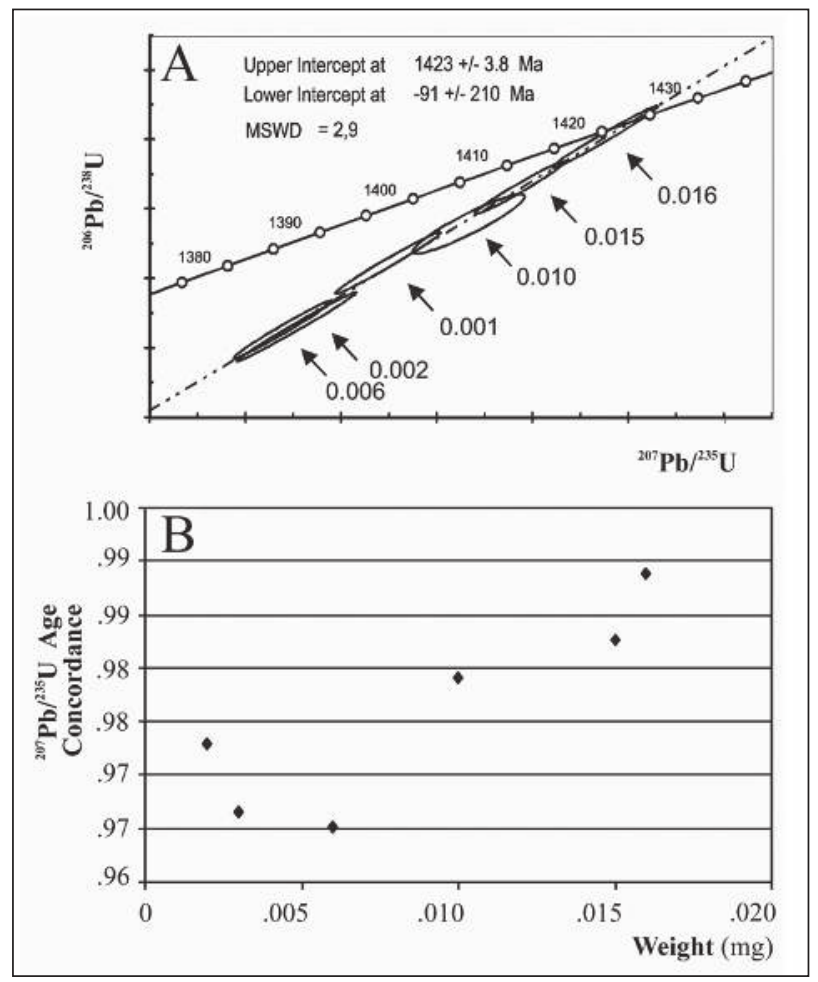

Figure $1 \mathrm{~A}$. U-Pb isotopic results plotted in the Concordia diagram; B. Grain Weight (mg) versus ${ }^{205} \mathrm{~Pb} /{ }^{235} \mathrm{U}$ Age Concordance $(\%)$. The weight values are in $\mathrm{mg}$. Concordance was calculated with respect to the upper intercept age $(1423 \pm 3.6 \mathrm{Ma})$.

For BSE imaging and Raman scattering spectroscopy, zircon grains were hand-picked and prepared in a standard mount. To avoid the loss of crystals during the polishing process, only grains of the same size were mounted together using low luminescence resin. No special sample preparation is required for Raman scattering analysis, whereas the BSE technique requires a carbon coating on the polished surface. The zircon grains were analysed using a CCD T64000 Jobin-Yvon laser-Raman microprobe at the Fluid Inclusion Laboratory of the Geosciences Institute of the State University of Campinas (Brazil). The Ar-ion laser wavelength used in the experiments was $514.5 \mathrm{~nm}$ (the strongest green line).
The theoretical diffraction-limited spot diameter on the sample surface was approximately $1 \mu \mathrm{m}$ for the Olympus $80 \times$ long working distance objective. The laser power impinging on sample surface is $10 \mathrm{~mW}$, which is typically non-destructive to samples of geologic interest. For BSE, $180^{\circ}$ backscattered light was detected with a $25.4 \mathrm{~mm}, 1024$ element diode-array optical detector.

\subsection{ID-TIMS Dating}

$\mathrm{U}-\mathrm{Pb}$ (single grain) zircon geochronology was performed on a granitic sample. The analysed zircon grains were clear, slightly caramel in colour, with rounded ends and short prismatic lateral faces. The studied grains present sizes varying from large, medium and small grains. Six zircon crystals were analysed, and the results, when plotted in the Concordia diagram, yielded an upper intercept age of $1423.0 \pm 3.8 \mathrm{Ma}$ (Figure 1A), which may be interpreted as the crystallization age of the rock, as discussed below. Each one of the analysed zircon grains had a different weight, and when the analytical results were plotted in the Concordia diagram, the heaviest zircon grain $(0.018 \mathrm{mg})$ was the most concordant $(99 \%)$.

To understand the isotopic patterns of the grains, a second diagram was plotted (Figure 1B) comparing Grain Weight $(\mathrm{mg})$ versus ${ }^{205} \mathrm{~Pb} /{ }^{235} \mathrm{U}$ Age Concordance (\%) so that the results indicate that $\mathrm{U}-\mathrm{Pb}$ isotopes are volume-dependent in the studied zircon grains.

\subsection{BSE Imaging}

BSE images reveal brightness contrasts related to the average atomic number of areas studied in a mineral: the higher the atomic number, the more electrons will be reflected and the brighter that region will appear. BSE imaging is used for a variety of geologic studies and is recognised as a powerful tool for studying zonation in accessory minerals (Hanchar \& Miller, 1993). In zircon, Hf is the main element responsible for the variability of the BSE intensity, with $U$ having a secondary effect. Both elements have a much higher atomic number than the 
principal constituents of zircon ( $\mathrm{Zr}, \mathrm{Si}$ and $\mathrm{O})$; thus, the substitution of $\mathrm{Zr}$ by $\mathrm{U}$ and $\mathrm{Hf}$ results in increased brightness (Nicola et al. 1974).

Figure 2 shows zircon grains (BSE images) from the granitic sample used in this study. The grains have a euhedral external shape and fine-scale euhedral oscillatory zoning. Magmatic zoned zircon crystals were found, indicating that the granitic samples have not suffered metamorphic heating or any other process resulting in new phases. Other than that, BSE images can provide further information, especially about inclusions showing they are frequently apparent in the sampled zircon crystals and might cause problems in performing $\mathrm{U}-\mathrm{Pb}$ dating and Raman scattering analysis (Parkinson \& Katayama, 1999).

\subsection{Raman Scattering Monitoring}

The Raman scattering spectrum of zircon is sensitive to its degree of metamictization. With decreasing crystallinity, the Raman bands become less intense (half-width peak variation) and increasingly broadened (area peak variation) and exhibit a shift to lower frequencies (shift of wavelength). In a synthetic single crystal of zircon, there are 36 first-order Raman-active modes, which are subdivided into internal and external vibrations (Syme et al., 1977). External vibrations are related to massive silicate complexes (rotational and translational motions), and internal vibrations are related to silicon-oxygen and metal-silicate bonds and sites. We analysed the metamictization degree using the half-width of the Raman bands calculated in three different (modes) peaks: (Eg) $360 \mathrm{~cm}^{-1}$, (A1g) 978 $\mathrm{cm}^{-1}$ and (B1g) $1012 \mathrm{~cm}^{-1}$. The objective was to identify the best or the most sensitive Raman scattering parameter to metamictization.

Conventional Raman scattering spectroscopy analysis in zircon involves determining the peak shift, half-width and peak area. In this study we get, from the Raman scattering spectra, a plot of the intensity of the inelastically scattered radiation (measured in photons per second) as a function of the halfwidth in each analysed spot (Fialin et al., 1977). The mechanical configuration of a high-resolution monochromator in combination with an argon ion laser as the excitation source enables the monitoring of the Raman scattering shift within the scale of the profile on the zircon surface.

In this way, the Raman scattering technique was used to obtain vibrational spectroscopic characteristics from the zircon lattice that is correlated to structural variations. The individual measurement spots can be seen in the backscattered electron images (Figure 2). Three zircon grains were analysed with profiles through the zoning areas on the zircon surface. The results illustrated in Figure 3, indicate that the increasing width of the internal (B1g mode) vibration (anti-symmetric stretching of $\mathrm{SiO}_{4}$ tetrahedral) is sensitive enough to determine the increasing degree of metamictization. Furthermore, evidence for metamictization is shown in Figure 4. These results indicate a marked heterogeneity of the halfwidth values of the represented three peaks, with a decreasing trending from the centre to the border in the three studied grains.

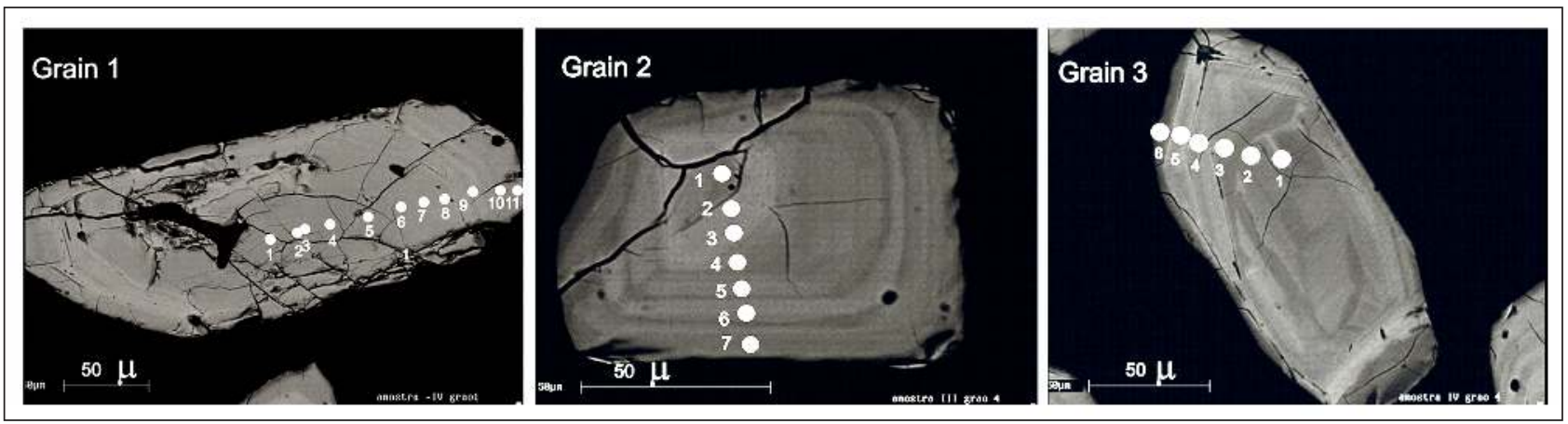

Figure 2 Zircon grains backscattered images. Raman scattering analyses were performed in the cross section shown on the grains. The zircon grains have a euhedral external shape and fine-scale euhedral oscillatory zoning, which indicates their igneous origin. 


\section{Discussion and Conclusions}

We report the results of a combined ID-TIMS and Raman microprobe study in order to evaluate the correlation between metamictization and U-Pb isotopic discordance of zircon. The spatial resolution of the Raman scattering probe allows for a direct comparison of the U-Pb isotopic discordance and the metamictization of the zoned areas within a zircon crystal. The combination of the two measurements also provides information on the $\mathrm{Pb}$ loss. We found that the degree of $\mathrm{U}-\mathrm{Pb}$ isotopic discordance is closely correlated with the volume of the zircon grain. The data, in addition to the lateral degree of metamictization detected by the Raman scattering technique, indicate that the loss of radiogenic $\mathrm{Pb}$ may be linked to continuous diffusion of this element (Watson \& Harrison, 1983; Levchenkov et al., 1998).

The correlation of U-Pb discordance and metamictization emphasizes the importance of the Raman scattering spectroscopy analysis to performing zircon dating. Indeed, it is a helpful tool for geochronologists. Because discordant isotopic ratios may provide ambiguous ages, it is advantageous to select zircon with well-ordered lattices for the age measurements. The results of the investigation here reported also suggest that a linear array of data points on the Concordia diagram is linked to the $\mathrm{Pb}$ loss. According to the literature (Krough, 1973), the concordance is directly proportional to the magnetic susceptibility of the zircon grain and also linked to metamictization.

Oscillatory zoning is a common feature in zircon from acidic igneous rock and is believed to form during zircon crystallisation from magma. The ID-TIMS and Raman scattering spectra herein presented above indicate that $\mathrm{Pb}$ diffusivity in slightly damaged zircon is not negligible and that $\mathrm{Pb}$ loss is not restricted to zircon that have experienced episodic $\mathrm{Pb}$ loss (e.g., U-Pb mineral systems opened during a secondary event) or a protracted low-temperature (annealing) history (Gerbauer \& Grunefelder, 1979). The analytical points defining a Discordia reported here (Figure 1) corroborate the hypothesis in which the radiogenic lead was lost by continuous diffusion (Cherniak et al., 1996, 1997), and the upper intercept age closely approaches the age of the formation of the rock.
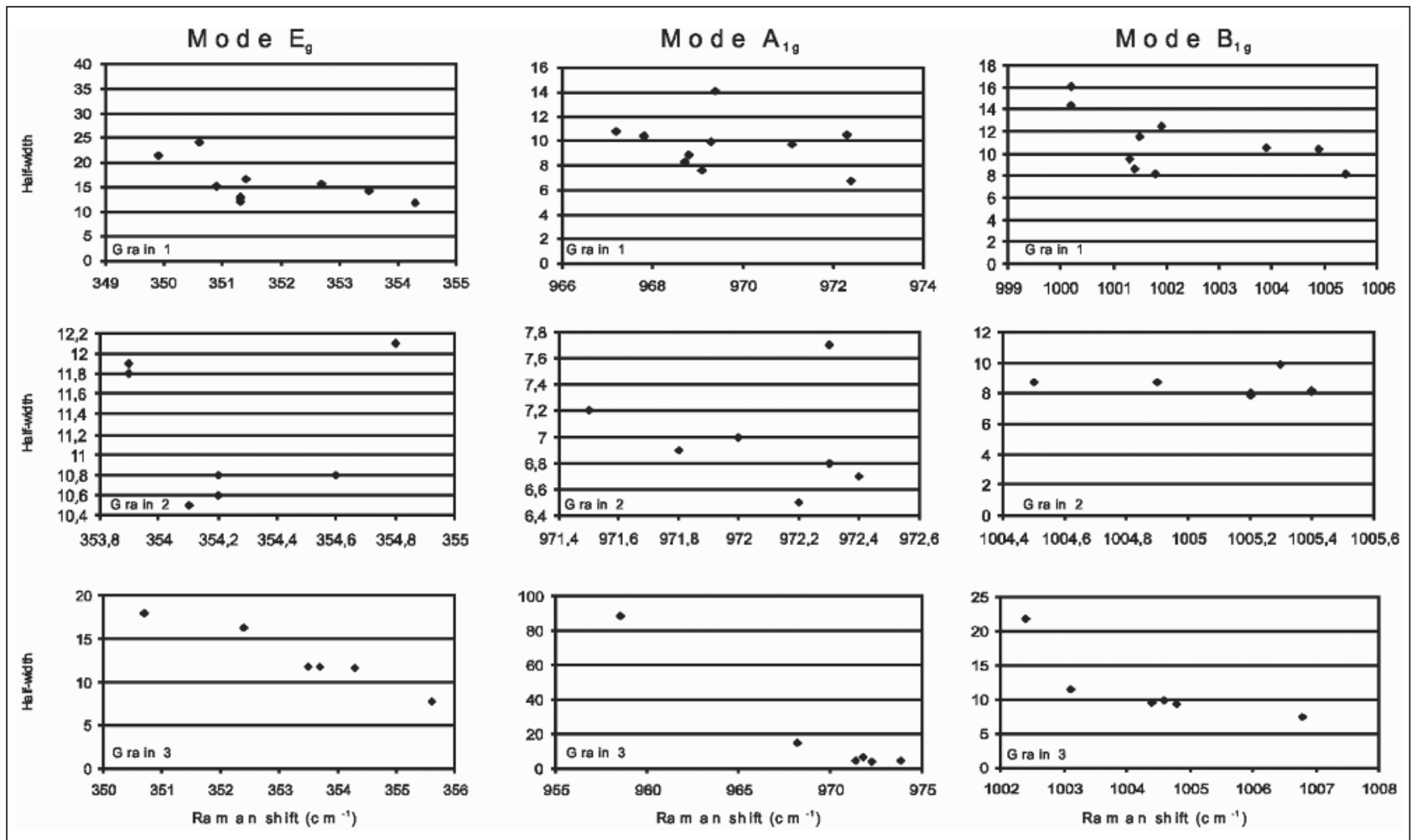

Figure 3 Raman results for three zircon grain profiles (shown in Figure 2). Three peaks $\left(360 \mathrm{~cm}^{-1}, 978 \mathrm{~cm}^{-1}\right.$ and $\left.1012 \mathrm{~cm}^{-1}\right)$ were studied using half-width as a parameter. Metamictization evidence is given by a significant heterogeneity of the half-width values. 


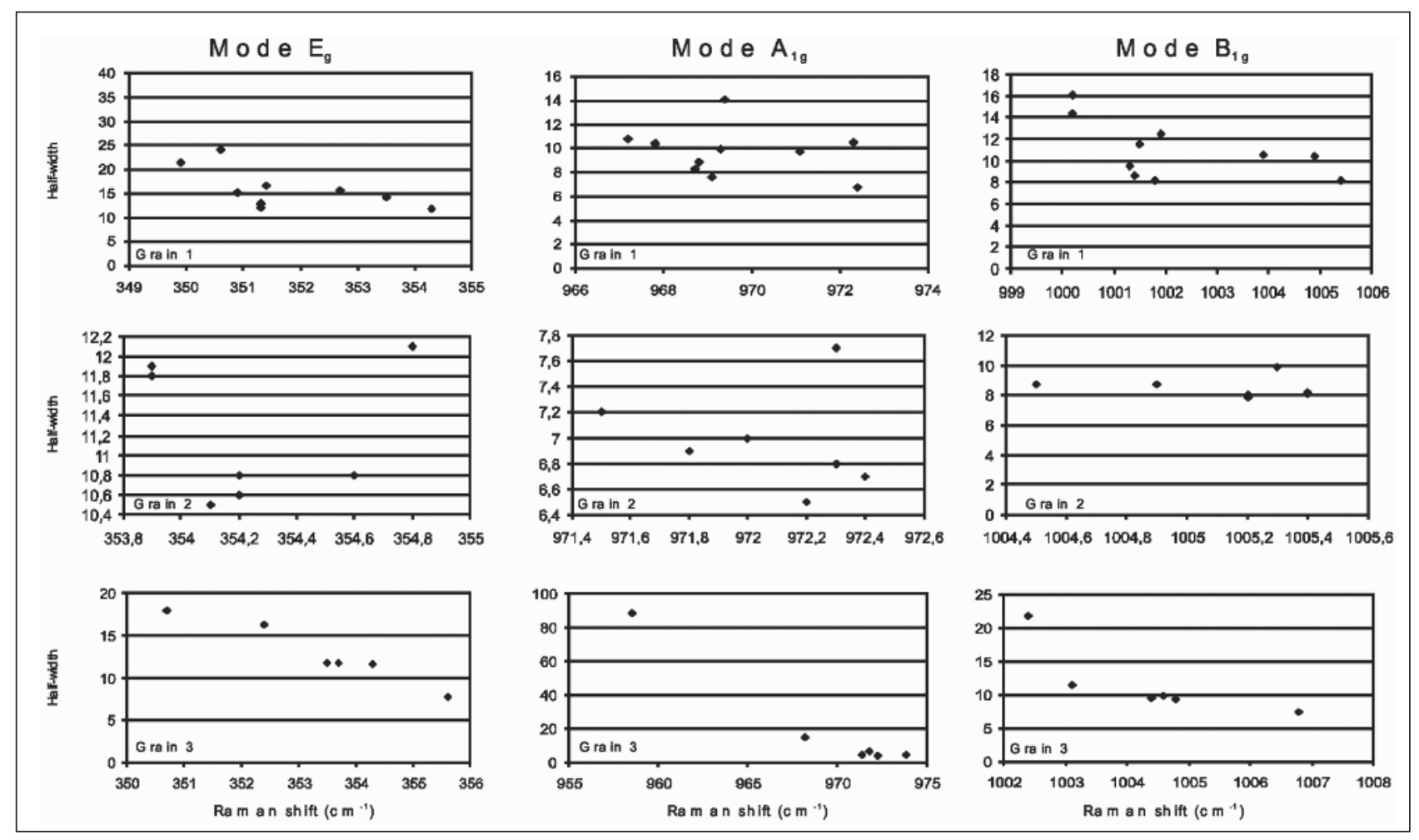

Figure 4 Raman spectra of zircon grains illustrates first-order Raman-active modes observed in the samples here studied.

\section{References}

Balan, E.; Neuville, D.R.; Trocellier, P.; Fritsch, E.; Muller, J-P. \& Calas, G. 2001. Metamictization and chemical durability of detrital zircon. American Mineralogist, 86: 1025-1033.

Cherniak, D.J.; Hanchar, J.M. \& Watson, E.B. 1996. Rare earth diffusion in zircon. Chemical Geology, 136: 289-301.

Cherniak, D.J.; Hanchar, J.M. \& Watson, E.B. 1997. Diffusion of tetravalent cations in zircon. Contributions to Mineralogy and Petrology, 127: 383-390.

Ewing, R.C.; Lutze, W. \& Weber, J. 1995. Zircon: A host-phase for the disposal of weapons plutonium. Journal of Materials Research, 10: 243-246.

Fialin, M.; Outrequin, M. \& Staub, PF. 1997. A new tool to treat peak overlaps in electron probe microanalysis of rare-earth-element L-series X-rays. European Journal of Mineralogy, 9: 965-968.

Gebauer, D. \& Grünefelder, M. 1979. U-Th-Pb dating of minerals. In: JÄGER, E. \& HUNZIKER, J.C. (Eds.). Lectures in Isotope Geology. Springer, p. 105-131.

Geraldes, M.C.; Van Schmus, W.R.; Condie, K.C.; Bell, S.; Teixeira, W. \& Babinski, M. 2001. Proterozoic Geologic Evolution of the SW part of the Amazonian Craton in Mato Grosso State, Brazil. Precambrian Research, 111: 91-128.

Hanchar, J.M. \& Miller, C.F. 1993. Zircon zonation patterns as revealed by cathodoluminescence and backscattered electron images: implications for interpretation of com- plex crustal histories. Chemical Geology, 110:1-13.

Hartmann, L.A.; Takehara, L.; Leite, J.A.D.; McNaughton, N.J. \& Vasconcellos, M.A.Z. 1997. Fracture sealing in zircon as evaluated by electron microprobe analyses and back-scattered electron imaging. Chemical Geology, 141: 67-72.

Jolliff, B.L.; Openka, B.; Zinner, E. \& Krenser, D.T. 1995. A zoned lunar zircon in a quartz-monzodiorite breccia from Apollo 14: U, Th, other trace elements, and Raman spectral parameters. Lunar and Planetary Science, XXVI: 695-696.

Knittle, E. \& Williams, Q. 1993. High-pressure Raman spectroscopy of $\mathrm{ZrSiO}_{4}$ : Observation of the zircon to scheelite transition at $300 \mathrm{~K}$. American Mineralogist, 78: 245-252.

Krogh, T.E. 1973. A low-contamination method for hydrothermal decomposition of zircon and extraction of $\mathrm{U}$ and $\mathrm{Pb}$ for isotopic age determinations. Geochimica et Cosmochimica Acta, 37: 485-494.

Krogh, T.E. 1982. Improved accuracy of U-Pb zircon ages by the creation of more concordant systems using an air abrasion technique. Geochimica et Cosmochimica Acta, 46: 637-649.

Levchenkov, O.A.; Rizvanova, N.G.; Maslenikov, A.V.; Makeev, A.F.; Bezmen, N.I. \& Levsky, L.K. 1998. Kinetics of $\mathrm{Pb}$ and $\mathrm{U}$ loss from metamict zircon under different P-T-X conditions. Geochimica International, 36: 1006-1013.

Ludwig, K.L. 1998. On the treatment of concordant uranium- 
-lead ages. Geochimica et Cosmochimica Acta, 46: 665-676.

Nasdala, L.; Götze, J.; Pidgeon, R.T.; Kempe, U. \& Seifert, T. 1998a. Contribution to Mineralogy and Petrology, 132: 300-306.

Nasdala, L.; Wenzel, T.; Pidgeon, R.T. \& Kronz, A. 1999. Internal structures and dating of complex zircons from Meissen Massif monzonites, Saxony. Chemical Geology, 156: 331-341.

Nasdala, L.; Pidgeon, R.T. \& Wolf, D. 1996. Heterogenous metamictization of zircon on a microscale, Geochimica et Cosmochimica Acta, 60: 1091-1097.

Nasdala, L.; Pidgeon, R.T.; Wolf, D. \& Irmer, G. 1998b. Metamictization and $\mathrm{U}-\mathrm{Pb}$ discordance in single zircons: a combined Raman microprobe and SHRIMP ion probe study. Mineralogy and Petrology, 62: 1-27.

Nicola, J.H. \& Rutt, H.N. 1974. Comparative study of zircon ( $\mathrm{ZrSiO} 4)$ and hafnon (HfSiO4) Raman-spectra. Journal of Physics C: Solid State Physics, 7: 1381-1386.

Parkinson, C.D. \& Katayama, I. 1999. Present-day ultrahigh-pressure conditions of coesite inclusions in zircon and garnet: Evidence from laser Raman microspectroscopy. Geology, 27(11): 979-982.

Parrish, R.R. 1987. An improved micro-capsule for zircon dissolution in U-Pb geochronology. Chemical geology (Isotope Geoscience Section), 66: 99-102.

Pidgeon, R.T. 1992. Recrystallization of oscillatory zoned zir- con: Some geochronological and petrological implications. Contribution to Mineralogy and Petrology, 110: 463-472.

Poller, U.; Liebetrau, V. \& Todt, G. 1997. U-Pb single-zircon dating under cathodoluminescence control (CLC-method): application to polymetamorphic orthogneisses. Chemical Geology, 139: 287-297.

Stacey, J.S. \& Kramers, J.D. 1975. Approximation of terrestrial lead isotope evolution by a two-stage model. Earth and Planetary Science Letters, 26: 207-221.

Steiger, R.H. \& Jäger, E. 1977. Sub commission on geochronology: Conventions on the use of decay constants in geo- and cosmochronology. Earth and Planetary Science Letters, 36: 359-362.

Syme, R.W.G.; Lockwood, D.J. \& Kerr, H.J. 1977. Raman spectrum of synthetic zircon ( $\mathrm{ZrSiO} 4)$ and thorite (ThSiO4). Journal of Physics C: Solid State Physics, 10: 13351348.

Watson, E.B. \& Harrison, T.M. 1983. Zircon saturation revisited: Temperature and composition effects in a variety of crustal magma types. Earth and Planetary Science Letters, 64: 295-304.

Wopenka, B.; Jolliff, B.L.; Zinner, E. \& Kremser, D.T. 1996. Trace element zoning and incipient metamictization in a lunar zircon; application of three microprobe techniques. American Mineralogist, 81: 902-912. 